International Journal of Oceanography and Hydrobiology Volume 50, No. 2, June 2021

\title{
The foraminiferal record in the Holocene evolution of the Mecklenburg Bay (south-western Baltic Sea)
}

by

\author{
Robert Kostecki ${ }^{1}$, \\ Teresa Radziejewska ${ }^{2, *}$
}

\section{DOI: 10.2478/oandhs-2021-0016 \\ Category: Original research paper \\ Received: October 28, 2020 \\ Accepted: January 4, 2021}

'Institute of Geoecology and Geoinformation, Faculty of Geographical and Geological Sciences, Adam Mickiewicz University in Poznań, ul. Bogumiła Krygowskiego 10, 61-680 Poznań, Poland

${ }^{2}$ Institute of Marine and Environmental Sciences, University of Szczecin, ul. A. Mickiewicza 16A, 70-383 Szczecin, Poland

\begin{abstract}
Foraminiferal assemblages were analyzed in a $620-\mathrm{cm}$ long core retrieved from the central part of the Mecklenburg Bay (MB, south-western Baltic Sea) to aid in the reconstruction of environmental changes occurring in the area during the Holocene and to complement a set of previously investigated palaeoenvironmental proxies. A total of five foraminifera-based stratigraphic units were identified, including an initial $80-\mathrm{cm}$ thick layer devoid of foraminifera. The next two units featured an increasing abundance of the foraminiferal assemblage dominated by the calcareous Ammonia group species. Nearly all the calcareous foraminifera found in the core were decalcified. Following the maximum abundance within the 470-410 $\mathrm{cm}$ layer, the foraminiferal abundance declined sharply and the assemblage's dominance structure changed to domination of the agglutinated foraminiferal species, Eggerelloides scaber, which continued up to the top of the core and marked a pronounced shift in environmental conditions (shallower depth, lower salinity, more dynamic sedimentation conditions). The foraminifera-based stratigraphy of the core proved to be complementary to that emerging from previous analyses of diatoms and sediment geochemistry.
\end{abstract}

Key words: Foraminifera, decalcification, environmental changes, Littorina transgression, canonical correlation analysis, Mecklenburg Bay

* Corresponding author: *teresa.radziejewska@usz.edu.pl 


\section{Introduction}

The present-day Baltic Sea, one of the world's largest bodies of brackish water (Snoeijs-Leijonmalm \& Andrén 2017), has evolved into its current shape as a result of complex processes initiated by the Weichselian Ice Sheet retreat about 15000 cal years BP (Björck 2008). The formation of the contemporary Baltic Sea proceeded through a number of stages, each marked by changes, occasionally drastic, in the basin and its ecosystem, particularly in terms of spatial extent, salinity and water level, these characteristics themselves being related to profound large-scale climate changes that affected the global sea levels (Weckström et al. 2017). Although the history of changes in the Baltic sea level and salinity - the major harbingers of the changing state of the basin - has already been fairly comprehensively described (e.g. Andrén et al. 2011; Weckström et al. 2017 and references therein), it is well established that different parts of the present-day Baltic basin have been subject to changes of varying rate, extent and conformity with the general pattern across the Baltic Sea (e.g. Björck et al. 2008). Therefore, reconstruction of the post-glacial evolution of such areas remains an important step in compiling a comprehensive and detailed picture of the history of the entire basin, particularly important in view of the currently observed effects (e.g. uplift of land masses in the north, sea transgression and coastline retreat in the south, climate changes) in the Baltic Sea (HELCOM 2013).

The Mecklenburg Bay (MB), an embayment located in the south-western part of the Baltic Sea, is one of the critical areas in which post-glacial changes reconstructed so far appear to be out of synchrony with changes inferred to occur elsewhere in the Baltic Sea (Kortekaas et al. 2007; Kostecki et al. 2015; Heinrich et al. 2018). Located between the Danish Straits - a transitional area connecting the Baltic Sea with the North Sea - and the Baltic Sea proper, $M B$ is more or less directly exposed to saline water inflows from the North Sea, the inflows being a major driver of current changes in the Baltic Sea ecosystem (Snoeijs-Leijonmalm \& Andrén 2017). The inflows are inferred to have been of major importance also in the evolution of the Baltic Sea (e.g. Binczewska et al. 2018). Due to the geographic setting of $M B$, the reconstruction of its post-glacial changes can provide important information on the overall dynamics of the Holocene evolution, making this area very important for palaeoenvironmental research, particularly for resolving details of the transition between the Ancylus Lake and the brackish Littorina Sea sensu lato, which is considered to be very complex (Björck 2008; Björck et al. 2008; Andrén et al. 2011; Weckström et al. 2017).

Hofmann and Winn (2000) referred to studies indicating that during the terminal phase of the Weichselian glaciation, today's MB was a freshwater, narrow and elongated lake, the largest and broadest in a series of lakes formed in the western Baltic Sea. The lake, along with the remaining part of what is today the western Baltic Sea, was separated by a natural dam from marine waters entering the Baltic area during the subsequent Yoldia stage, characterized by brackish and cold water, and was not affected by them. On the other hand, during the next stage (Ancylus), the reduced lake in today's MB was connected with the main Ancylus Lake.

Following up on the earlier work of other authors (Witkowski et al. 2005; Rößler 2006; Rößler et al. 2011), Kostecki et al. (2015) used an array of palaeoceanographic proxies (including diatom record, geochemistry and lithology), in addition to acoustic profiling and radiocarbon dating of three cores collected at different sites in $\mathrm{MB}$, to reconstruct the timeline of some fundamental changes in the area. In brief, their analyses demonstrated that the MB sediments recorded the sequence of the Baltic Ice Lake (BIL), the Ancylus Lake, and the Littorina and Post-Littorina Sea stages. The final drainage of BIL completed the deposition of clayey sediments that covered the glacial till floor. The Ancylus Lake stage is marked by the presence of layers of sandy silt, gyttja, and peat typical of lacustrine and swampy environments. Similarly to the findings reported by Hofmann and Winn (2000), the sediment record analyzed by Kostecki et al. (2015) indicates the presence of an isolated shallow lake. This freshwater reservoir, inferred to have existed between 8800 and 7700 cal years BP, experienced weak seawater inflows depositing sandy silt and mud, which reflects the initial Littorina Sea stage (Witkowski et al. 2005; Rößler et al. 2011; Kostecki et al. 2015). The main Littorina Sea transgression began in the area about 7700-7500 cal years BP (Witkowski et al. 2005; Kostecki et al. 2015), i.e. several hundred years earlier than the transgression recorded in the Arkona Basin. This period was represented by mud deposited in a marine environment with relatively high salinity. The upper mud layer reflects the last 3000 years of the youngest Baltic Sea stage, i.e. the post-Littorina Sea characterized by reduced (brackish) salinity.

In this study, we examined the foraminiferal record in Core 317980-3, one of the three cores that Kostecki et al. (2015) used in their reconstructions. Our analysis serves a dual purpose. Firstly, we provide data that contribute to expanding the body of knowledge about the Baltic Sea foraminifera, a still insufficiently 
known component of the Baltic Sea diversity, both today (cf. Snoeijs-Leijonmalm 2017) and in the palaeorecord (Binczewska et al. 2018). Secondly, we complement the analyses performed by Kostecki et al. (2015) and compare the information provided by the foraminiferal record in the core with the conclusions drawn from the analyses of other proxies (diatoms, sediment geochemistry). In so doing, we address the question posed by Seddon et al. (2014) as to whether the proxies used in palaeoenvironmental reconstructions are comparable in terms of their sensitivity to environmental changes, and whether they are complementary or equally useful for adequate temporal resolution of the changes inferred.

\section{Study area}

The Mecklenburg Bay (MB; Fig. 1) is a shallow basin in the south-western part of the Baltic Sea, with the maximum depth of $28 \mathrm{~m}$ and a fairly complex shoreline. The bay includes two larger sub-basins (the Bay of Wismar and the Bay of Lübeck) and connects to the Kiel Bight in the west via the Fehmarn Belt.
MB is separated from the Arkona Basin of the Baltic Sea proper by the shallow (average depth of $15 \mathrm{~m}$ ) rise known as the Darss Sill (Kostecki et al., 2015), intersected by the Kadet Channel (Kadetrinne) connecting MB with the Baltic Sea proper (Bennike and Jensen 1998; Zettler et al. 2001). The water exchange between MB and the Baltic Sea proper is subjected to meteorological forcing (Powilleit et al. 2006), with temperatures varying throughout the year between $1.76-17.9$ and $2.05-12.3^{\circ} \mathrm{C}$ at the surface and in the near-bottom water, respectively (Matthäus 1986). The average salinity of $\mathrm{MB}$ varies within a wide range of 10-20 (Powilleit et al. 2006). The water column is frequently stratified (particularly during the summer season; Matthäus 1984), with the pycnocline occurring in the central part of MB at about 12-16 $\mathrm{m}$ (Siegel et al. 2009). Salinity above the pycnocline varies within 9-16, and ranges within 15-22 below it (Gogina et al. 2010). The near-bottom water layer in the central (deepest) part of MB shows regular, short, late-summer episodes of oxygen depletion, i.e. hypoxia (Powilleit et al. 2006; Gogina et al. 2010), and even anoxia (Janßen et al. 2014). The natural sedimentation and sediment accumulation rates were estimated at $1-3 \mathrm{~mm} \mathrm{yr}^{-1}$ and

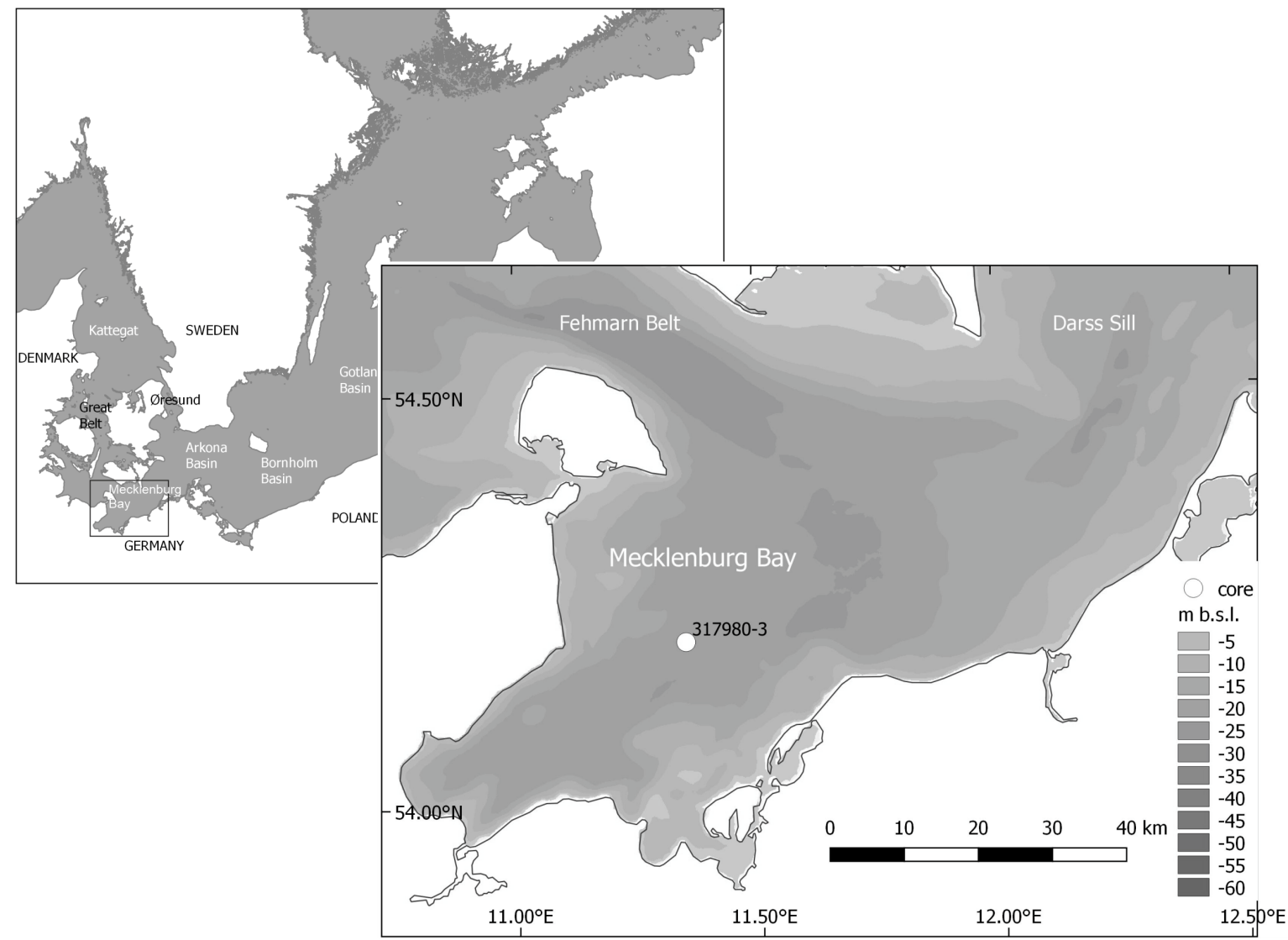

Figure 1

Location of the Core 317980-3 collection site in the Mecklenburg Bay (south-western Baltic Sea) 
about $300 \mathrm{~g} \mathrm{~m}^{-2} \mathrm{yr}^{-1}$, respectively (Leipe et al. 2005), and the particulate organic carbon (POC) accumulation (burial) rate was estimated at $20-30 \mathrm{~g} \mathrm{~m}^{-2} \mathrm{yr}^{-1}$ (Leipe et al. 2011). Despite stagnant conditions in the central part of $M B$, sediment lamination is prevented by bioturbation, deep winter mixing and sediment resuspension (Kostecki et al. 2015).

\section{Materials and methods}

\subsection{Coring and subsampling}

The sediment for this study was obtained from Core 317980-3 collected in the central part of MB (Fig. 1) with a gravity corer during the RV Maria S. Merian cruise in 2006 . The coring site $\left(54^{\circ} 12.01^{\prime} \mathrm{N}\right.$; $11^{\circ} 21.010^{\prime} \mathrm{E}$ ) was located at a depth of $21.8 \mathrm{~m}$.

Upon retrieval, the core was divided into 1-m long sections and stored under refrigeration. A 0-620 cm core section was used for the analysis of foraminifera. Prior to subsampling and analyses, the core was visually inspected and four lithological units were distinguished. The lowest unit (620-615 $\mathrm{cm}$ ) consisted of light grey sandy clay. It was overlain by a $10-\mathrm{cm}$ thick layer of brownish-black peat gyttja separated by a sharp boundary from the bottom layer. The peat gyttja was covered by a layer (605-575 $\mathrm{cm}$ ) of brown-grey sandy silt with a more gradational contact. The top part of the core $(575-0 \mathrm{~cm})$ consisted of sand-containing mud, its colour changing visibly from dark grey to light olive-grey and the sand content decreasing upwards. Small shells of the bivalves Limecola (formerly Macoma) sp. and Mytilus sp. were found at depths of 509-495, 462-450, 390 and 50 $\mathrm{cm}$. The uppermost $10-\mathrm{cm}$ core layer was dark grey in colour and exuded a typical $\mathrm{H}_{2} \mathrm{~S}$ smell (Kostecki et al. 2015). Other properties of the core are summarized in Kostecki et al. (2015).

The core was cut into $1-\mathrm{cm}$ sections from which subsamples were retrieved for lithological, geochemical and diatomological analyses (summarized by Kostecki et al. 2015). As described in Kostecki et al. (2015), the bivalve shells found (Limecola sp. and Mytilus sp.) as well as the bulk sediment (peat gyttja) were used for radiocarbon dating conducted at the Poznań Radiocarbon Laboratory, using the ${ }^{14} \mathrm{C}$ accelerator mass spectrometry (AMS). Dates from the lacustrine deposits were calibrated using appropriate software (CALIB 8.1 radiocarbon calibration programme - Stuiver \& Reimer 1993 as well as Marine20 and IntCal20 - Heaton et al. 2020 and Reimer et al. 2020). The calibrated dates were used to develop an age-depth model for Core 317980-3.
Sediment portions for the foraminiferal analysis were collected at $5-\mathrm{cm}$ intervals. These samples were placed in plastic bags and stored in the refrigerator $\left(4^{\circ} \mathrm{C}\right)$ until the analysis.

\subsection{Sample processing}

The sediment portion to be analyzed was placed in a $1-\mathrm{dm}^{3}$ beaker, covered with $0.6 \mathrm{dm}^{3}$ water and left for $24 \mathrm{~h}$ in the refrigerator $\left(7^{\circ} \mathrm{C}\right)$. Subsequently, the sediment was stirred with a glass rod to disintegrate clumps and the beaker content was passed through a set of sieves (mesh sizes: 0.5; 0.250; 0.180; 0.090 and $0.063 \mathrm{~mm}$ ). The residue from each sieve was rinsed onto Petri dishes, covered with water and examined under a stereomicroscope. Any foraminifera found were identified and counted. As the calcareous (rotaliids) and some arenaceous (trochamminids) foraminifera found in finer sediment fractions (sieving residues on 0.063 and $0.090 \mathrm{~mm}$ mesh size sieves) were seldom intact (see below), and were represented mostly by fragments, a foraminifera individual was considered as such and counted whenever the fragment found consisted of at least one whorl. Whorl fragments were disregarded. Whenever the state of preservation allowed, the foraminifera were identified to at least the genus level (consulting inter alia Loeblich \& Tappan 1988; Murray \& Alve 2011). The foraminiferal nomenclature was checked against the World Register of Marine Species database (WoRMS; www. marinespecies.org). Upon completion of the analysis of a sample, the sieving residues were combined, dried $\left(105^{\circ} \mathrm{C}\right)$ for $24 \mathrm{~h}$ and weighed on a precision laboratory balance (Ohaus). The foraminiferal abundance is referred to as the number of individuals per gram dry sediment ( $\mathrm{g}$ d.s.). As the finest $(<0.063 \mathrm{~mm})$ sediment fraction was lost on sieving, the "sediment" is understood as the sum of sediment fractions coarser than $0.063 \mathrm{~mm}$.

Examination of the sieving residues allowed to complement the visual inspection of the whole core (see above) with some details observed under the microscope (e.g. the presence of plant and invertebrate remains such as ostracod valves, variable proportion of sand etc.; (f. Table 1).

\subsection{Data treatment}

Associations between the sedimentary environmental variables described in an earlier paper (Kostecki et al. 2015) and abundances of the dominant foraminifera groups determined in this study were analyzed using the Canonical Correlation Analysis (CCA). In our case, CCA was used to look for 


\begin{tabular}{|c|c|c|c|c|}
\hline $\begin{array}{l}\text { Foraminifera - } \\
\text { based unit (F) and } \\
\text { age (cal yrs BP) }\end{array}$ & $\begin{array}{l}\text { Core layer } \\
(\mathrm{cm})\end{array}$ & Assemblage characteristics & Sediment characteristics & Notes and comments \\
\hline $\begin{array}{c}\text { F1 } \\
+10700-\text { c. } 8100\end{array}$ & $620-540$ & No foraminifera & $\begin{array}{l}\text { Admixture of fine sand; sulphide } \\
\text { micronodules in the deepest layer; } \\
\text { abundant fine and coarse plant } \\
\text { remains (including seeds and } \\
\text { characean oogonia), freshwater } \\
\text { mollusc shell fragments }\end{array}$ & $\begin{array}{l}\text { Abundant cladoceran fauna } \\
(600-540 \mathrm{~cm}) \text {; occasional } \\
\text { shells of limnic ostracods }\end{array}$ \\
\hline $\begin{array}{c}\text { F2 } \\
\text { c. } 8100-\text {-c. } 6900\end{array}$ & $540-470$ & $\begin{array}{l}\text { Foraminifera present; abundance fluctuates, } \\
\text { but gradually increases to peak at } 475-480 \\
\mathrm{~cm} \text {, and to decline thereafter; almost } 100 \% \\
\text { domination of the Ammonia group, with a } \\
\text { slight admixture of arenaceous forms; C/A } \\
\text { ratio strongly in favour of calcareous forms }\end{array}$ & $\begin{array}{l}\text { The lowest layer still with cladoceran } \\
\text { fragments; mud with admixture of } \\
\text { fine sand; abundant plant remains }\end{array}$ & $\begin{array}{l}\text { Occasional hydrobiid snail } \\
\text { shell fragments }\end{array}$ \\
\hline $\begin{array}{c}\mathrm{F} 4 \\
\text { c. } 6300-\text { c. } 3000\end{array}$ & 410-175 & $\begin{array}{l}\text { Abrupt decline in abundance; C/A ratio still in } \\
\text { favour of calcareous forms, but agglutinated } \\
\text { forms gaining in importance }\end{array}$ & $\begin{array}{l}\text { Mud; occasionally abundant plant } \\
\text { remains; admixture of fine sand }\end{array}$ & $\begin{array}{l}\text { Fragments of mollusc } \\
\text { shells; occasional valves } \\
\text { of fresh- and brackish- } \\
\text { water ostracods as well as } \\
\text { cladoceran ephippia and } \\
\text { carapace fragments }\end{array}$ \\
\hline $\begin{array}{c}\text { F5 } \\
\text { c. } 3000-\text { present }\end{array}$ & $175-0$ & $\begin{array}{c}\text { Fluctuating, generally low abundance } \\
\text { (except for one layer with an exceptionally } \\
\text { high abundance peak); domination of } \\
\text { Eggerelloides scaber; C/A ratio very strongly in } \\
\text { favour of agglutinated forms }\end{array}$ & $\begin{array}{l}\text { Plant remains; admixture of } \\
\text { fine sand; occasional sulphide } \\
\text { micronodules }\end{array}$ & $\begin{array}{l}\text { Mollusc shell fragments } \\
\text { (e.g. Cardium), occasionally } \\
\text { abundant; valves of } \\
\text { fresh- and brackish-water } \\
\text { ostracods }\end{array}$ \\
\hline
\end{tabular}

linear combinations of environmental variables (the $X$ variables: mean grain size as well as the contents of terrigenous and biogenic silica, magnesium and calcium determined in 126 samples) which produced the best correlations with linear combinations of the groups of foraminiferal taxa (the $\mathrm{Y}$ variables: the Ammonia group, Eggerelloides scaber, Trochamminacea, Reophax sp.). CCA was performed using R CRAN packages: CCA (González et al. 2008; González \& Déjean 2009) and CCP (Menzel 2009) freely available in the $R$ Archive Network. The data were transformed using the $\log (x+1)$ function to normalize their distributions. The relationships between the environment parameters and foraminifera were inferred from canonical dimensions visualized on the ordination diagram of the most significant CCA coefficients.

\section{Results}

\subsection{The state of preservation of foraminifera found in the samples}

The calcareous (rotaliid) foraminifera present in the sediment were mostly decalcified and occurred as organic shell linings (Fig. 2) or fragments thereof.
The decalcified forms were identified as representing mainly two species of Ammonia (see below). The agglutinated forms, on the other hand, were usually well preserved, although the finer sediment fractions contained fragments (occasionally unidentifiable) of agglutinated foraminifera as well.

\subsection{Core chronology}

The ${ }^{14} \mathrm{C}$ dating of the core showed it to reflect the sediment structure extending as far back as to about 10800 cal yrs BP (Fig. 3). The radiocarbon dates, albeit sparse, suggest continuous sedimentation and the absence of hiatuses. The depth-age model developed served as a timeframe for the foraminiferal record obtained from the core.

\subsection{The occurrence of foraminifera and their assemblage structure}

The deepest sediment layers $(620-540 \mathrm{~cm}$, c. 10 700-6900 cal yrs BP) were devoid of foraminifera which began to appear from the level of $535 \mathrm{~cm}$ up and were then present in most of the layers (except for 205-200, i.e. c. 3500 cal yrs BP, and 170-165 cm, i.e. c. 3000 cal yrs BP). 

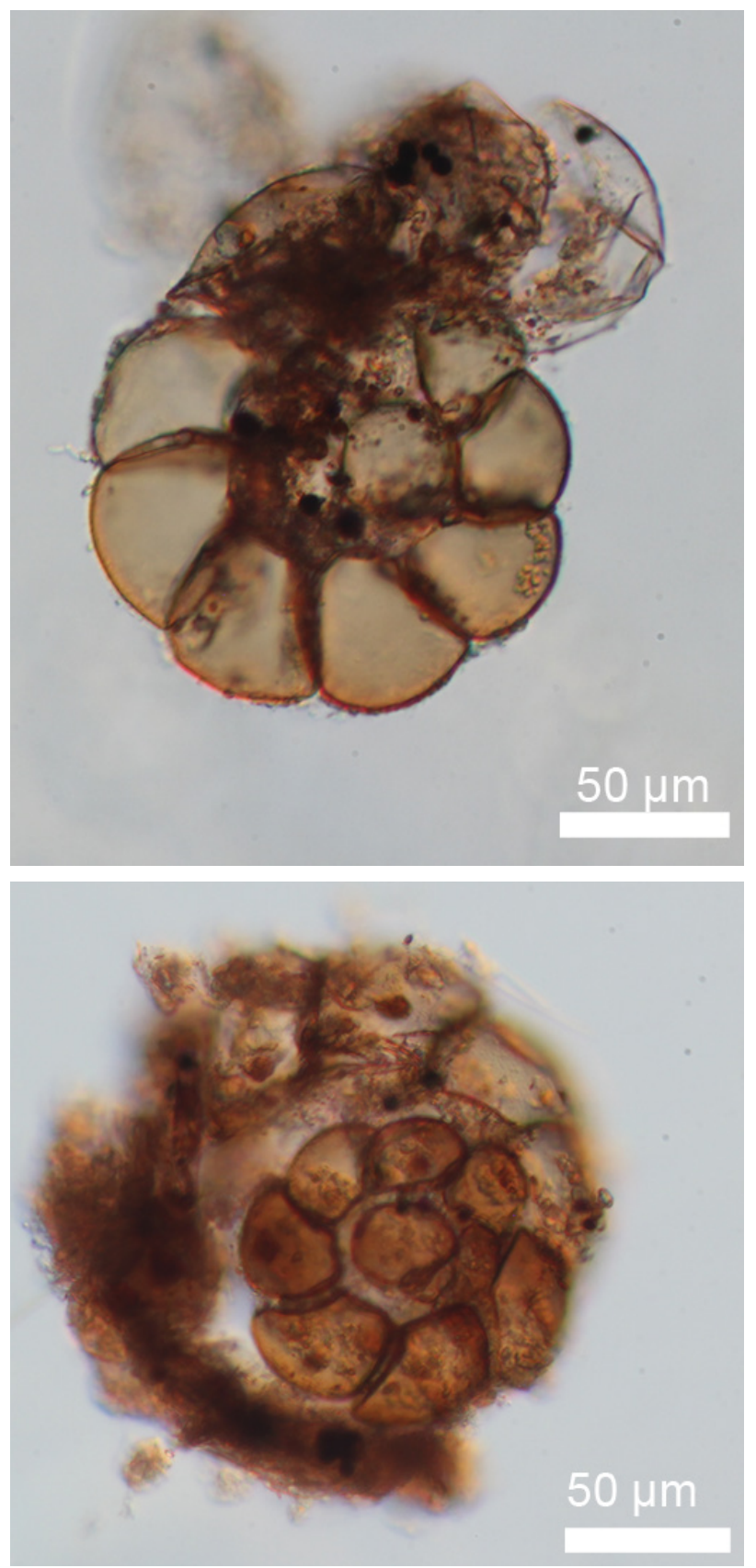

Figure 2

Decalcified tests of Ammonia foraminifera from Core 317980-3

The study revealed the presence of a total of 13 foraminiferal taxa (including the collective Ammonia group; see below). The foraminifera found in the samples analyzed were represented by calcareous (hyaline) and agglutinated forms.

Most of the calcareous forms, belonging to the Rotaliidae, were assigned to the genus Ammonia and most likely represented the species $A$. beccarii and
A. batava. However, the vast majority of the specimens occurred as organic shell linings (see above; Fig. 2) and decalcification prevented species identification. This, as well as the nomenclatural uncertainty regarding the taxonomic identification of individual Ammonia species (Hayward et al. 2004) and the lack of molecular confirmation of the identity of the specimens found, resulted in these forms being hereafter referred to as representing a higher-rank collective taxon, the Ammonia group. One layer $(55-50 \mathrm{~cm}$; c. $1400 \mathrm{cal}$ yrs BP) showed the presence of representatives of the genus Elphidium (E. incertum, E. excavatum, and Elphidium sp.).

The agglutinated forms included Adercotryma sp., Ammoscalaria sp., Eggerelloides scaber, Miliammina fusca, Reophax cf. dentaliniformis, Textularia cf. kattegatensis and the Trochamminacea.

While some of the taxa identified (notably representatives of the Ammonia group) occurred throughout the foraminifera-containing part of the core (Fig. 3), others appeared either intermittently or were observed in some sediment layers only. In this context, it is interesting to note that Eggerelloides scaber, which first appeared in the 495-490 cm layer in the core (c. $7500 \mathrm{cal}$ yrs BP), became a permanent member of the foraminiferal associations from the 200-195 cm layer (c. 3500 cal yrs BP) upward, and was virtually the only taxon found in the uppermost $45 \mathrm{~cm}$ layer.

The number of taxa was low throughout most of the core length, with basically monogeneric assemblages occurring at the opposite ends of the foraminifera-containing section. The first monogeneric assemblage occurred in the $540-500 \mathrm{~cm}$ section (c. 8100-7500 cal yrs BP) and consisted of the Ammonia group, while the other monogeneric (or even monospecific) assemblage, characterized by the exclusive presence of $E$. scaber, was recorded within the $40-5 \mathrm{~cm}$ layer (Fig. 3). The maximum taxonomic richness was observed within the $425-420 \mathrm{~cm}$ (five taxa) and $55-50 \mathrm{~cm}$ (six taxa) layers.

\subsection{Abundance of foraminifera}

The abundance of foraminifera ranged from 0 to 1854.23 ind. $\mathrm{g}^{-1}$ d.s. The abundance profile (Fig. 3) showed a sequence of peaks and troughs above the layer of sediment devoid of foraminifera, with three prominent peaks: the first (505.52 ind. $\mathrm{g}^{-1}$ d.s.) within the $480-475 \mathrm{~cm}$ layer, the second being the maximum abundance observed within the 450-445 cm layer (c. $6900 \mathrm{cal}$ yrs BP), and the third (761.05 ind. $\mathrm{g}^{-1}$ d.s.) recorded within the $55-50 \mathrm{~cm}$ layer (c. $1400 \mathrm{cal}$ yrs BP). 


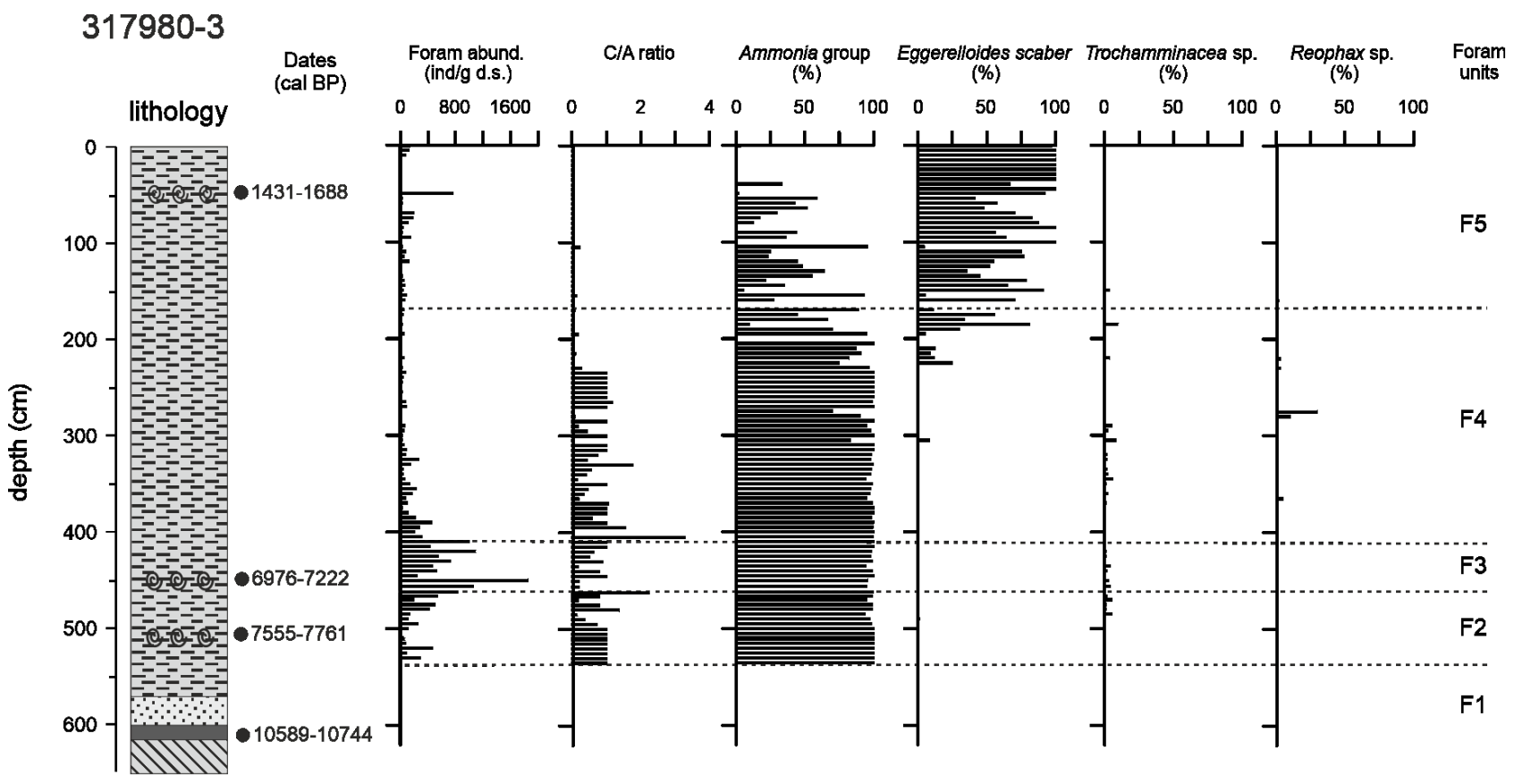

and silt

Figure 3

Distribution of dominant foraminiferal assemblages in Core 317980-3 [age-depth model developed from radiocarbon dates after Kostecki et al. (2015) using CALIB 8.1 radiocarbon calibration programme (Stuiver and Reimer 1993) as well as Marine20 and IntCal20 curves (Heaton et al. 2020; Reimer et al. 2020)]; C/A ratio - calcareous to agglutinated foraminifera ratio

\subsection{Calcareous to agglutinated (C/A) foraminifera ratio}

The proportion of calcareous to agglutinated foraminifera presents a very characteristic pattern (Fig. 3): calcareous forms accounted for up to $100 \%$ of the assemblage from the bottom of the foraminiferacontaining section to the $190-185 \mathrm{~cm}$ layer. From this point on, the structure of the assemblage changes significantly. The proportions of calcareous to agglutinated forms begin to reverse, almost a mirror reflection-like, and the assemblage rapidly becomes dominated by agglutinated forms. Eventually, from about $50 \mathrm{~cm}$ in the core to the top, they account almost without exception - for up to $100 \%$ of the assemblage, with E. scaber being the dominant (and frequently the only) taxon.

\subsection{Foraminifera-based stratigraphy of Core 317980-3}

Based on the abundance of foraminifera along the core and other assemblage characteristics, the profile can be divided into five more or less distinct foraminifera-based units (F1-F5; Table 1) distributed from the bottom to the top of the core.

Unit F1 consists of the foraminifera-free part (up to $540 \mathrm{~cm}$ in the core; c. 8100 cal yrs BP). Unit F2 (540-470 cm; c. 8100-6900 cal yrs BP) features the first appearance of foraminifera and a gradual increase in their abundance to a peak (505.52 ind. $\mathrm{g}^{-1}$ d.s.) within the $480-475 \mathrm{~cm}$ layer, followed by a decline. The foraminiferal assemblage in Unit F2 is dominated by the Ammonia group, with a slight admixture of agglutinated forms (notably Reophax cf. dentaliniformis, trochamminids and the sparse E. scaber). Unit F3, covering the 470-410 cm layer (c. 6900-6300 cal yrs $\mathrm{BP})$, is the most distinct feature of the entire profile, with the maximum overall abundance (1854.23 ind. $\mathrm{g}^{-1}$ d.s.) recorded at a depth of $450-445 \mathrm{~cm}$ in the sediment. The composition of the foraminiferal assemblage is most complex there, with the highest overall number of taxa recorded. Foraminifera of the Ammonia group dominate, but agglutinated forms (primarily $R$. cf. dentaliniformis, trochamminids, and Ammoscalaria sp.) are fairly well represented. 
Occasionally, the foraminiferal assemblage is accompanied by brackish-water ostracods (Cyprideis torosa). Unit F4, from $410 \mathrm{~cm}$ to $175 \mathrm{~cm}$ in the core (c. $6300-3000 \mathrm{cal}$ yrs BP), is characterized by an abrupt decline in the foraminiferal abundance to generally low levels, with an undulating sequence of small peaks and troughs along the length of the core toward the top, and by a gradual shift in the community composition in which agglutinated forms (dominated by $E$. scaber) gain in importance from the 180-175 cm layer (c. 3000 cal yrs BP). Occasionally, the microfossil non-diatom assemblage contains valves of fresh- and brackish-water ostracods (Cypria ophtalmica and Cyprideis torosa) and cladoceran remains. Unit F5, from $175 \mathrm{~cm}$ (c. 3000 cal yrs BP) to the top of the core, is characterized by generally low foraminiferal abundances, including layers devoid of foraminifera, and by the domination of E. scaber. In addition, the unit shows (within $55-50 \mathrm{~cm}$; c. $1400 \mathrm{cal}$ yrs BP) an unusual peak in the foraminiferal abundance (761.05 ind. $\mathrm{g}^{-1}$ d.s.), resulting from a strongly increased contribution of $E$. scaber, accompanied by the Ammonia group, Elphidium incertum and E. excavatum. Interestingly, all the Ammonia shells were decalcified, whereas those of Elphidium were not. The non-diatom microfossil assemblage found in the $55-50 \mathrm{~cm}$ layer contained also a collection of fresh- and brackish-water ostracods (Candona sp., Cyprideis torosa, Cytheropteron latissimum, Cytheromorpha fuscata, Loxoconcha elliptica, Acanthocythereis dunelmensis). This pronounced peak in the abundance of foraminifera is followed by a layer of very low abundances or a complete absence of foraminifera. The abundances increase again from 20-15 cm layer to the top (123.65-128.5 ind. $\mathrm{g}^{-1}$ d.s. in the topmost $10 \mathrm{~cm}$ layer), with the assemblage being strongly dominated by $E$. scaber.

\subsection{Relationships between foraminifera assemblages and sediment parameters}

CCA produced four canonical dimensions, the first two of which proved statistically significant $(p<0.05)$. The ordination diagram of the first two canonical dimensions is shown in Fig. 4, while correlations of the canonical dimensions with the sedimentary parameters analyzed and the foraminifera groups are summarized in Table 2. The first canonical dimension accounts for $82 \%$ of the association between the sediment parameters and the foraminiferal abundance, and the first two canonical dimensions together explain $92 \%$ of the relationship. The first canonical dimension is positively associated with the content of magnesium (0.58) and biogenic silica (0.56); the second canonical dimension is most closely

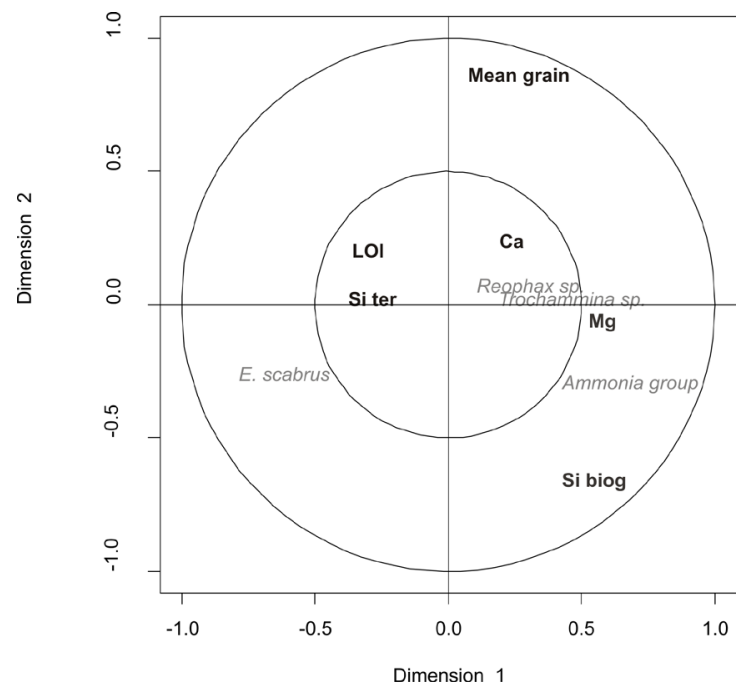

Figure 4

CCA ordination plot for the analysis of foraminifera and biogeochemical variables in Core 317980-3; LOI - loss on ignition; Mean grain - mean grain size; Si ter - terrigenous silica; Mg - magnesium content; Ca calcium content; Si biog - biogenic silica; geochemical data description published in Kostecki et al. (2015)

and positively associated with the mean grain size $(0.87)$ and negatively associated with the biogenic silica content $(-0.66)$. The first canonical dimension is positively associated with the Ammonia group (0.77), the Trochamminacea (0.55) and Reophax sp. (0.33), and negatively associated with $E$. scaber $(-0.76)$. The second dimension is negatively associated with the Ammonia group (-0.61) and the Trochamminacea sp. $(-0.55)$, no association with Reophax sp. (0.07) and E. scaber (0.05) being visible.

\section{Discussion}

\subsection{General remarks}

Analysis of Core 317980-3 from the Mecklenburg Bay (the south-western part of the Baltic Sea) showed the presence of a total of 13 foraminiferal taxa. Although generally indicative of low taxonomic diversity, the number of taxa found was more than twice as high as that reported by Binczewska et al. (2018), who found a total of six benthic foraminiferal species in their core collected from the Bornholm Basin (the central part of the Baltic Sea). This difference seems to be consistent with the general west-east diversity gradient of the Baltic Sea (Ojaveer et al. 2010; Snoeijs-Leijonmalm 2017). 
Table 2

Results of Canonical Correlation Analysis

\begin{tabular}{|c|c|c|c|c|}
\hline & \multicolumn{4}{|c|}{ Dimensions } \\
\hline & 1 & 2 & 3 & 4 \\
\hline Cumulative percentage of variance explained & 0.82 & 0.92 & 0.96 & 0.99 \\
\hline \multicolumn{5}{|c|}{ Environmental parameters } \\
\hline Si ter & -0.28 & 0.02 & -0.10 & 0.87 \\
\hline Si biog & 0.56 & -0.66 & -0.20 & -0.41 \\
\hline $\mathrm{Mg}$ & 0.58 & -0.01 & 0.01 & -0.56 \\
\hline LOI & -0.30 & 0.21 & -0.05 & -0.91 \\
\hline $\mathrm{Ca}$ & 0.23 & 0.25 & -0.21 & 0.05 \\
\hline Mean grain size & 0.20 & 0.87 & -0.08 & 0.34 \\
\hline \multicolumn{5}{|c|}{ Foraminifera taxa } \\
\hline Ammonia group & 0.77 & -0.61 & -0.18 & -0.02 \\
\hline Eggerelloides scaber & -0.76 & -0.55 & -0.32 & -0.06 \\
\hline Trochamminacea & 0.55 & 0.07 & -0.80 & 0.25 \\
\hline Reophax sp. & 0.33 & 0.05 & -0.65 & -0.69 \\
\hline
\end{tabular}

Our study revealed remains of fairly abundant foraminiferal assemblages in the central MB sediment layers dating back to the onset of the Littorina stage in the area. Previous studies in MB (e.g. Hofmann \& Winn 2000; Rößler 2006; Rößler et al. 2011) provided a rather inconsistent evidence regarding the presence of foraminifera in the area. Hofmann and Winn (2000), who collected two cores from MB (one in the innermost part, the Neustadt Bay, and the other in a more central location), found remains of foraminifera in the $0-310 \mathrm{~cm}$ section of their 494-cm long core from the Neustadt Bay, with the abundance of foraminifera forming peaks at 230 and $60 \mathrm{~cm}$ (the latter roughly coincident with our $55-50 \mathrm{~cm}$ peak). The abundances reported ranged within $2-51$ ind. $\mathrm{g}^{-1}$ wet sediment, a range not directly comparable with our abundance estimates, which were based on dry sediment. Hofmann and Winn (2000) provided no taxonomic identification, although they did mention that all the foraminifera found in their study represented the genera Ammonia and/or Elphidium, thus indirectly supporting our finding of the Ammonia group forms being dominant in the area (except for the upper part of our core). The other MB core of Hoffman and Winn (2000) yielded a single specimen, not identified taxonomically, found in the $38 \mathrm{~cm}$ sample.

Rößler (2006) referred to the abundance of foraminifera in her MB cores, although she did not provide any detailed list of the taxa found. She only mentioned that the foraminiferal assemblages appearing first in her MB cores were dominated by Ammonia batavus (an unaccepted synonym of A. batava; cf. World Register of Marine Species, http://www.marinespecies.org/aphia.php?p= taxdetails\&id=112848 accessed on 6 December 2020), other conspicuously occurring species including A. beccarii, Cribroelphidium williamsoni (= Elphidium williamsoni in WORMS http://www.marinespecies. org/aphia.php?p=taxdetails\&id=113291 accessed on 6 December 2020) and Haynesina germanica. In a subsequent analysis of four cores collected in MB, Rößler et al. (2011) did record the presence of foraminifera (see below), but again provided no information as to their taxonomic identity.

Based on published information and their own unpublished observations, Frenzel et al. (2005) produced a checklist of recent foraminifera from off the German Baltic coast, in which they summarized the knowledge about taxonomic richness in MB. They listed a total of 29 taxa (3 allogromiid, 14 agglutinated and 12 calcareous). Our material contains much fewer taxa, but all of them were already recorded from $M B$, even though they may have been referred to by Frenzel et al. (2005) under names that are not currently accepted (e.g. Nodulina dentaliniformis instead of Reophax dentaliniformis etc.). It is worth noting, however, that the list of MB foraminiferal taxa in Frenzel et al. (2005) does not contain Eggerelloides scaber, a species featuring so prominently in our material, particularly in the upper part of the core. Frenzel et al. (2005) did refer to it, but - quoting Murray (1991) - used the currently invalid names Eggerelloides scabrus and Egerella (sic!) scabra, the former being a dweller of higher-salinity areas in the open Baltic Sea and a key species of sand and mud associations, and the latter being used to denote a species (apparently the same one) included in the Ammotium cassis association occurring in the organic matter-enriched sediment in the inner Baltic Sea. 


\subsection{Characteristics of the most important taxa found}

Among the calcareous taxa in our material, the most important were members of the Ammonia group, most likely Ammonia beccarii, a euryhaline species typical of shallow nearshore areas, estuaries and salt marshes, reported from numerous locations worldwide (e.g. Alve \& Murray 1999).

The agglutinated foraminiferal taxa found in this work are characteristic of marginal marine areas (Murray \& Alve 2011) and/or waters with reduced salinity. The most abundant agglutinated taxa in the samples included Eggerelloides scaber, Trochamminacea, Reophax cf. dentaliniformis, and Miliammina fusca. E. scaber has been described as "infaunal, detritivorous, subtidal, mainly shelf but tolerates salinity $>24$ for most of the year and temperatures $1-20^{\circ} \mathrm{C}^{\prime \prime}$ (Murray \& Alve 2011). Alve and Nagy (1986) showed E. scaber to be the most abundant species in Sandebukta on the west coast of Sweden, with no substrate preference. Christiansen et al. (1996) reported the species (as E. scabrus, currently an unaccepted synonym; World Register of Marine Species http://www.marinespecies.org/ aphia.php? $p=$ taxdetails\&id=113939; accessed on 6 December 2020) as the most abundant foraminifera in the 130-140 mm layer of their short cores from the Kattegat. They described the species as tolerant of poor environmental conditions and resistant to pollution. Reophax dentaliniformis (referred to as Nodulina dentaliniformis by e.g. Murray \& Alve 1999 and Frenzel et al. 2005) is a widely distributed species, found in both recent and sub-recent sediments of the Baltic Sea at different depths, as far east as the Gotland and Gdańsk Deeps (Hermelin 1983, 1987; A. Binczewska, pers. comm.). Miliammina fusca is another widely distributed species whose abundant occurrence was reported in the southern Baltic Sea (Brodniewicz 1965). It is very common and relatively abundant on the shallow (5-8 $\mathrm{m}$ ) sandy bottom in the inshore areas of the Pomeranian Bay (southern Baltic Sea; T. Radziejewska, unpubl. data).

\subsection{State of preservation}

As in the study by Binczewska et al. (2018), the calcareous forms in our core (primarily the Ammonia group) occurred - in the vast majority of samples - as completely or partially decalcified organic test linings (cf. Fig. 2), somewhat similar to the photograph (Plate II 5) in Murray \& Alve (1999). The post-mortem decalcification/dissolution of foraminiferal tests is a widespread and well-known effect (e.g. Christiansen et al. 1996; Leckie \& Olson 2003; Buzas-Stephens 2005; Murray \& Alve 2011; Haynert et al. 2012; Binczewska et al. 2018; Buzas-Stephens et al. 2018). To quote Murray and Alve (2011), "There is abundant evidence of syndepositional dissolution of calcareous tests in certain modern environments including both terrigenous and carbonate sediments" (p. 11). Christiansen et al. (1996) found abundant dissolutionaffected foraminifera in the lower part (below $6 \mathrm{~cm}$ ) of their core; they assigned most of those remains to Ammonia batava. Leckie and Olsen (2003) paid a particular attention to the taphonomic loss of calcareous species due to carbonate dissolution. They specifically referred to Ammonia, the preservation potential of which is adversely affected by acidic (low pH) conditions associated with organic-rich substrate. In Texas bays, Buzas-Stephens (2005) and Buzas-Stephens et al. (2018) found a high proportion of living foraminifers, almost exclusively Ammonia sp., with shells damaged by decalcification. They attributed this to acidic conditions prevailing in the sediment contaminated with heavy metals, and resulting in part from pyritization (evidenced by framboidal pyrite visible in shells of live specimens), a stress response in foraminifera. It can therefore be postulated, in line with conclusions of Binczewska et al. (2018), that the Ammonia-dominated foraminiferal assemblages observed in our core were developing in a brackish-water sedimentary environment, in fine-grained sediment substantially enriched with organic material (including that of plant origin, as exemplified by plant remains visible in the sieving residue examined), where - due to the decomposition of that material - the pore water $\mathrm{pH}$ was reduced (cf. Reaves, 1986).

The calcareous foraminifera test dissolution makes the sample processing technique very important. If samples contain decalcified tests, drying the sediment and examining dried samples for the presence of foraminifera, a widely adopted practice (e.g. Murray, 2002), would make it very difficult to spot the delicate shell linings of calcareous forms. We (and others: A. Binczewska and Z. Stachowska, pers. comm., Binczewska et al. 2018) experienced this difficulty before switching to examining sediment samples in water, whereby the linings were very well visible. As we used $>0.063 \mathrm{~mm}$ sieves, some fine sediment residue was lost during sample processing. However, we do not consider the loss of the finest material to be a factor that could affect the foraminiferal abundance data. More relevant in this respect could have been the fragmentation of test linings, as only fragments containing at least one whorl were counted, and whorl fragments were disregarded (see Sample processing 
above). For this reason, the total abundances presented may be treated as underestimates, but the extent of the underestimation cannot be assessed.

Interestingly, the calcareous forms found in MB cores by Rößler (2006) and Rößler et al. (2011) preserved their carbonate shells, enabling the authors to use those foraminifera for dating.

As opposed to the calcareous foraminifera, and in contrast to the findings of Binczewska et al. (2018), the agglutinated foraminifera found in our material were generally well-preserved, the numbers of damaged individuals and/or test fragments being generally very low.

\subsection{C/A ratio}

We have grounds to assume that the reversal of the $\mathrm{C} / \mathrm{A}$ ratio in the upper part of the core is not an artefact produced by dissolution of calcareous forms and the resultant "(...) higher abundance of agglutinated tests in the dead assemblages than could be accounted for by differential production between species." (Murray and Alve, 2011). Because we analyzed non-dried sediment material, we would have recorded any organic test lining present in the sample, which was the case in the lower part of the core. We can therefore argue that the pattern observed reflects a true shift in the community composition. Assuming, after Levin (2003), that arenaceous tests are energetically less costly to form and maintain than the calcareous ones, the strong preponderance of agglutinated foraminifera in the upper part of the core can be taken as evidence of environmental conditions becoming increasingly stressful in terms of e.g. reduced oxygenation of the near-bottom water layer and pore water and/ or reduced salinity, for calcareous forms to exist (e.g. Iglikowska \& Pawłowska 2015). Leckie and Olson (2003) found a marked increase in the abundance of calcareous taxa to accompany the transition from brackish marginal habitats to open neritic conditions. Similarly, Valchev (2003) attributed a shift in the C/A ratio in favour of arenaceous (i.e. agglutinated) foraminifera to low-salinity water undersaturated in calcium carbonate. We may thus conclude that a marked change in the $\mathrm{C} / \mathrm{A}$ ratio observed in our core signified a transition to a less saline and more stressful environment in MB prevailing to date.

\subsection{Foraminifera-based stratigraphy and environmental effects}

No foraminifera remains were found in the deepest part of the core (Unit F1; 615-610 and 615-540 cm), i.e. the sediment older than 10700 to 8100 cal yrs BP (cf. Fig. 3), attributed to the final stage of the Baltic Ice Lake $(620-615 \mathrm{~cm})$ and especially the Ancylus Lake phases (Kostecki et al. 2015). On the other hand, the sediment throughout the $615-540 \mathrm{~cm}$ layer contained extremely abundant cladoceran remains (carapace fragments and ephippia). Although no formal study on cladoceran proxies was carried out, the remains were identified as representing carapace fragments of the dominant Bosmina longispina, accompanied by Alona quadrangularis, A. affinis, Chydorus sphaericus, Ch. piger, Leydigia leydigi, Pleuroxus uncinatus, Alonella nana, Bosmina longirostris, Eurycercus lamellatus, Acroperus harpae, Camptocercus rectirostris and L. acathocecoides (A. Kaniak, pers. comm.). These species, representing a typically freshwater assemblage, testify to the lacustrine nature of the environment recorded by the sediment in this layer, the presence of some cold-water species (e.g. B. longispina, Ch. sphaericus, A. nana; Zawisza \& Szeroczyńska 2007) evidencing the low-temperature phase in the MB evolution. This oldest, Ancylus Lake-derived section of the core corresponds to the Ancylus Lake $(A L)$ section of the Bornholm Basin core analyzed by Binczewska et al. (2018), also lacking (or nearly lacking) foraminifera and featuring abundant cladoceran remains. According to Binczewska et al. (2018), however, their AL section corresponded to the period of 7100-6900 cal yrs BP, thus later than the Ancylus Lake stage occurring in MB. It seems that while the Ancylus Lake stage was still prevalent in the Bornholm Basin, MB in the western part of the present-day Baltic Sea began to experience a shift toward the next stage of the Baltic Sea evolution - the Littorina Sea stage.

The overlying layer (Unit F2, 540-470 cm; c. 8100-6900 cal yrs BP), where foraminifera begin to appear, marks the onset of the transition in the nature of the area toward the Littorina Sea stage. The sporadic hydrobiid snail shell fragments (cf. Table 1) may be indicative of the shallowness of the area. The subsequent layer (Unit F3, 470-410 cm; c. 6900-6300 cal yrs BP) coincides with the beginning of the earlyand mid-Littorina Sea stage (LS) of Binczewska et al. (2018). In our core, this stage is characterized by the highest abundance of foraminifera (cf. Fig. 3), also reported by Binczewska et al. (2018), and the assemblage is dominated by the calcareous Ammonia group (Elphidium spp. in the case of the Bornholm Basin). The sediment characteristics (cf. Table 1 and Kostecki et al. 2015) are indicative of a deep low-energy depositional environment. The 410-175 cm layer (Unit F4; c. 6300-3000 cal yrs BP, coinciding with the later part of the early- and mid-LS stage of Binczewska et al. 2018) shows a decline in the abundance of foraminifera 
and a change in the assemblage structure, whereby the previously dominant calcareous forms give way to the domination of agglutinating foraminifera (E. scaber), which is particularly well visible in the uppermost unit (F5; C. 3000 cal yrs BP-present; cf. Table 1). As already mentioned, agglutinated foraminifera are known to usually dominate at lower salinities, and a change from a calcareous to an agglutinated assemblage visible in the sedimentary record may be taken as evidence of a change (reduction) in salinity (Leckie and Olson, 2003; Buzas-Stephens et al. 2018). The stage in question corresponds to the late-LS stage of Binczewska et al. (2018), characterized by low salinities and the domination of Reophax dentaliniformis, an agglutinated species occurring with low densities, and the scarcity or absence of calcareous foraminifera.

The pattern emerging from the analysis of our core is confirmed by the CCA results (cf. Fig. 4). The first CCA dimension (with the highest and significant correlation with magnesium and biogenic silica contents) can be considered to be related to salinity fluctuations, with magnesium regarded as a salinity proxy (cf. Ruiz-Agudo et al. 2010). Elevated salinity can be inferred from the higher contents of magnesium and biogenic silica that accompanied the abundant presence of the Ammonia group foraminifera (and - to a much lesser extent -the Trochamminacea). The biogenic silica content reflected the presence of an abundant marine diatom flora (Kostecki et al. 2015), also indirectly indicating an environment with higher salinity. Rößler (2006) observed the MB calcareous foraminifera peak to coincide with peaks in the sediment calcium carbonate, with both magnesium and calcium being components of biogenic marine carbonates (Ruiz-Agudo et al. 2010). The Ammonia group (and to a lesser extent Reophax sp. and the Trochamminacea) were the most abundant foraminifera during the period of increasing salinity, while the presence of $E$. scaber should be related to the period of decreasing salinity. In this context, it is noteworthy that Polovodova et al. (2009) considered E. scaber as an indicator of increased salinity: they interpreted the decline in the species' abundance in the Flensburg Fjord as an indication of reduced incidence of saline oxygen-rich water inflows. In our study, however, E. scaber was an absolute dominant in the uppermost stratigraphic unit related to the period of decreasing salinity in the Baltic Sea.

The second canonical dimension was strongly influenced by the mean grain size, and thus can be inferred to reflect changes in the depositional energy status of the area and its water depth. Higher values of the second dimension are related to shallow-water dynamic sedimentation affected by waves and currents, while low values relate to calmer sedimentation conditions at deeper water favoured by foraminiferal assemblages featuring the Ammonia group. The low correlations of trochamminids and Reophax sp. with the second dimension confirmed their preference for shallow-water habitats (Frenzel et al. 2005).

The foraminifera-based stratigraphy inferred from the analysis of Core 317980-3 (Table 1) is broadly similar to that based on the diatomological analysis of the same core (Kostecki et al., 2015). There are, however, some differences. The diatom LDAZ1 and LDAZ2 considered together coincide with the foraminiferabased unit F1 covering the core section devoid of foraminifera. The remains of freshwater diatoms in the fully lacustrine Ancylus phase represented by this section allowed us to fine-tune the resolution of various periods during that stage. On the other hand, the remaining core section reflects two diatom-based units (LDAZ3 and LDAZ4), whereas the foraminiferal analysis identified four units (F2-F5), refining the division resulting from the diatom analysis and coinciding broadly with the stratigraphy based on geochemical variables analyzed by Kostecki et al. (2015).

In view of the results presented in this study, we can conclude that the analysis of foraminifera complements the set of palaeoproxies used previously and provides additional information on the Holocene evolution of MB in its post-Ancylus Lake stages.

\section{Conclusions}

Analysis of Core 317980-3 retrieved from the Mecklenburg Bay (MB) in the south-western Baltic Sea revealed the presence of a total of 13 foraminiferal taxa (including the collective Ammonia group). Most of the calcareous forms represented the genus Ammonia (most likely $A$. beccarii and A. batava). The vast majority of specimens occurred as organic shell linings, and decalcification prevented species identification. Representatives of the Ammonia group occurred throughout most of the foraminifera-containing part of the core. Other species appeared either intermittently or were observed in some sediment layers only. The agglutinating species Eggerelloides scaber became a permanent member of the foraminiferal assemblages from the 200-195 cm layer (c. 3500 cal yrs BP) upward and was virtually the only taxon present in the uppermost $45 \mathrm{~cm}$ layer.

The taxonomic richness of foraminifera was low throughout most of the core length, with basically 
monogeneric or monospecific assemblages occurring at the opposite ends of the foraminifera-containing section.

A total of five foraminifera-based stratigraphic units were identified, including an initial $80-\mathrm{cm}$ thick layer devoid of foraminifera, and containing abundant cladoceran remains, indicating freshwater conditions of the Ancylus Lake. The next two units featured an increasing abundance of the foraminiferal assemblage dominated by the calcareous Ammonia group species. After reaching the maximum value within the 470-410 $\mathrm{cm}$ layer (c. 6900-6300 cal yrs BP), the foraminiferal abundances decreased abruptly and the assemblage became dominated by the agglutinated species Eggerelloides scaber up to the top of the core. This was an indication of a pronounced shift in environmental conditions (shallower depth, lower salinity, more dynamic sedimentation conditions).

The proportion of calcareous to agglutinated foraminifera (C/A ratio) showed a drastic reversal, at about 3300 cal yrs BP, from the assemblage dominated by calcareous forms to that dominated by agglutinated ones, which may signify a transition to a less saline and more stressful (in terms of e.g. reduced oxygenation of the near-bottom water layer and pore water) environment in MB prevailing to this day.

The foraminifera-based stratigraphy of Core 317980-3 was broadly similar to that based on the diatomological analysis of the same core, but comprised more units, which refined the division resulting from the diatom analysis. On the other hand, the foraminifera-based stratigraphy coincided with that based on geochemical proxies.

The comparison of the foraminiferal record emerging from Core 317980-3 (MB, south-western Baltic Sea) with the results of similar studies in the Bornholm Basin (BB) showed differences and similarities in foraminiferal assemblages in the two areas, reflecting more general similarities and differences in the evolution of the Baltic Sea. The similarities involved a generally low taxonomic richness (although higher in MB than in BB), a sediment layer lacking foraminifera and rich in Cladocera dating to the Ancylus Lake stage, the domination of low-diversity assemblages of calcareous foraminifera (strongly decalcified in both cases) throughout the Littorina Sea stage, and the prevalence of a single, agglutinated species in the late phase of the Littorina Sea stage to date. The differences involved the dominant taxa in $\mathrm{BB}$ and $\mathrm{MB}$, both calcareous (Elphidium spp. and Ammonia spp., respectively) and agglutinated (Reophax dentaliniformis and Eggerelloides scaber, respectively), but also reflected different timing of major palaeo-oceanographic events, with the onset of the Littorina Sea stage occurring earlier in MB than in $\mathrm{BB}$. Our results therefore support the notion that the Littorina transgression occurred earlier in $M B$ than in other parts of the Baltic Sea.

\section{Acknowledgements}

We thank Dr. Matthias Moros of the Leibniz Institute of the Baltic Sea Research (IOW) Warnemünde (Germany) for placing materials from Core 317980-3 at our disposal for the analysis of foraminifera. Our thanks are due to Ms. Anna Skrzypacz for supplying dry sediment weights, to Ms. Aleksandra Kaniak for identifying the cladocerans, and to Dr. Sławomir Dobosz for providing photographs of the foraminiferal test linings. We are grateful to Dr. Anna Binczewska for making the results of her research available to us prior to publication. We would also like to thank Professor Petra Heinz and Professor Peter Frenzel for critical reading of an earlier version of the manuscript and for helpful comments. Our thanks are due to an anonymous reviewer whose comments allowed us to improve the original version of the submitted paper. We are grateful also to the Oceanological and Hydrobiological Studies' editorial team for their contribution to the improvement of the submission.

The research described in this study was supported by the Polish National Science Centre grant No. 2011/01/B/ST10/06497 awarded to RK. TR acknowledges the support from the research subsidy provided by the Institute of Marine and Environmental Sciences, University of Szczecin, Poland.

\section{References}

Alve, E. \& Murray, J.W. (1999). Marginal marine environments of the Skagerrak and Kattegat: a baseline study of living (stained) benthic foraminiferal ecology. Palaeogeography, Palaeoclimatology, Palaeoecology 146: 171-193.

Alve, E. \& Nagy, J. (1986). Estuarine foraminiferal distribution in Sandebukta, a branch of the Oslo Fjord. Journal of Foraminiferal Research 16: 261-284.

Andrén, T., Björck, S., Andrén, E., Conley, D., Zillen, L. et al. (2011). The Development of the Baltic Sea Basin During the Last 130 ka. In J. Harff, S. Björck \& P. Hoth (Eds.), The Baltic Sea Basin (pp. 75-97). Springer: Berlin.

Bennike, O. \& Jensen, J. B. (1998). Late- and postglacial shore level changes in the south-western Baltic Sea. Bulletin of the Geological Society of Denmark 45: 27-38.

Björck, S. (2008). The late Quaternary development of the Baltic Sea basin. In H. von Storch (Ed.), Assessment of climate change in the Baltic Sea basin (pp. 398-407). 
Springer Verlag: Berlin Heidelberg.

Björck, S., Andrén, T. \& Jensen, J.B. (2008). An attempt to resolve the partly conflicting data and ideas on the Ancylus-Littorina transition. Polish Geological Institute Special Papers 23: 21-26.

Binczewska, A., Moros, M., Polovodova Asteman, I., Sławińska, J. \& Bąk, M. (2018). Changes in the inflow of saline water into the Bornholm Basin (SW Baltic Sea) during the past 7100 years - evidence from benthic foraminifera record. Boreas 47: 297-310.

Brodniewicz, I. (1965). Recent and some holocene foraminifera of the southern Baltic Sea. Acta Palaeontologica Polonica 10: 131-236.

Buzas-Stephens, P. (2005). Population dynamics and dissolution of foraminifera in Nueces Bay, Texas. Journal of Foraminiferal Research 35: 248-258.

Buzas-Stephens, P., Buzas, M., Price, J. \& Chandra, H.C. (2018). Benthic Superheroes: Living Foraminifera from Three Bays in the Mission-Aransas National Estuarine Research Reserve, USA. Estuaries and Coasts 41: 2368-2377. DOI: 10.1007/s12237-018-0425-4.

Christiansen, C., Kunzendorf, H., Laima, M.H.C., LundHansen, L.C. \& Pedersen, A.M. (1996). Recent changes in environmental conditions in the south-western Kattegat, Scandinavia. Norges Geologiske Undersøkelse Bulletin 430: 137-144.

Frenzel, P., Tech, T. \& Bartholdy, J. (2005). Checklist and annotated bibliography of Recent Foraminiferida from the German Baltic Sea coast. Studia Geologica Polonica 124: 67-86.

Gogina, M., Glockzin, M. \& Zettler, M.L. (2010). Distribution of benthic macrofaunal communities in the western Baltic Sea with regard to near-bottom environmental parameters. 1. Causal analysis. Journal of Marine Systems 79: 112-123.

González, I. \& Déjean, S. (2009). CCA: Canonical correlation analysis. Available at: https://cran.r-project.org/web/ packages/CCA.

González, I., Dèjean, S., Martin, P.G.P. \& Baccini, A. (2008). CCA: An R Package to Extend Canonical Correlation Analysis. Journal of Statistical Software 23: 128-129. DOI: 10.1002/ wics.10.

Haynert, K., Schönfeld, J., Polovodova Asteman, I. \& Thomsen, J. (2012). The benthic foraminiferal community in a naturally $\mathrm{CO}_{2}$-rich coastal habitat of the southwestern Baltic Sea. Biogeosciences 9: 4421-4440.

Hayward, B.W., Holzmann, M., Grenfell, H.R., Pawlowski, J. \& Triggs, C.M. (2004). Morphological distinction of molecular types in Ammonia - towards a taxonomic revision of the world's most commonly misidentified foraminifera. Marine Micropaleontology 50: 237-271.

Heaton, T.J., Köhler, P., Butzin, M., Bard, E., Reimer, R.W. et al. (2020). Marine20 - The Marine Radiocarbon Age Calibration Curve (0-55,000 cal BP). Radiocarbon 62: 237-
271.

Heinrich, C., Anders, S., Schwarzer, K. (2018). Late Pleistocene and early Holocene drainage events in the eastern Fehmarn Belt and Mecklenburg Bight, SW Baltic Sea. Boreas 46: 754-776.

HELCOM (2013). Climate change in the Baltic Sea Area: HELCOM thematic assessment in 2013. Baltic Sea Environment Proceedings 137.

Hermelin, J.O.R. (1983). Biogeographic patterns of modern Reophax dentaliniformis Brady (arenaceous benthic foraminifera) from the Baltic Sea. Journal of Foraminiferal Research 13: 155-162.

Hermelin, J.O.R. (1987). Distribution of Holocene benthic foraminifera in the Baltic Sea. Journal of Foraminiferal Research 17: 62-73.

Hofmann, W. \& Winn, K. (2000). The Littorina Transgression in the Western Baltic Sea as Indicated by Subfossil Chironomidae (Diptera) and Cladocera (Crustacea). International Review of Hydrobiology 85: 267-291.

Iglikowska, A. \& Pawłowska, J. (2015). The Adaptations of the Foraminifera and Ostracoda to Fresh Water Colonisation. In T. Zieliński, M. Węsławski \& K. Kuliński (Eds.), Impact of Climate Changes on Marine Environments (pp. 91-113) Springer: Dordrecht.

Janßen, H., Schröder, T., Zettler, M.L. \& Pollehne. F. (2015). Offshore wind farms in the southwestern Baltic Sea: A model study of regional impacts on oxygen conditions. Journal of Sea Research 95: 248-257.

Kortekaas, M., Murray, A., Sandgren, P. \& Björck, S. (2007). OSL chronology for a sediment core from the southern Baltic Sea: A continuous sedimentation record since deglaciation. Quaternary Geochronology 2: 95-101.

Kostecki, R., Janczak-Kostecka, B., Endler, M. \& Moros, M. (2015). The evolution of the Mecklenburg Bay environment in the Holocene in the light of multidisciplinary investigations of the sediment cores. Quaternary International 386: 226238.

Leckie, R.M. \& Olson, H.C. (2003). Foraminifera as Proxies for Sea-level Change on Siliciclastic Margins. In H.C. Olson \& R.M. Leckie (Eds.) Micropaleontologic Proxies for Sea-Level Change and Stratigraphic Discontinuities (pp. 5-19). SEPM (Society for Sedimentary Geology) Special Publication 75.

Leipe, T., Kersen, M., Heise, S., Pohl, C., Witt, G. et al. (2005). Ecotoxicity assessment of natural attenuation effects at ahistorical dumping site in the western Baltic Sea. Marine Pollution Bulletin 50: 446-459.

Leipe, T., Tauber, F., Vallius, H., Virtasalo, J., Uścinowicz, S. et al. (2011). Particulate organic carbon (POC) in surface sediments of the Baltic Sea. Geo-Marine Letters 31: 175188.

Levin, L.A. (2003). Oxygen minimum zone benthos: Adaptation and community response to hypoxia. Oceanography and Marine Biology Annual Review 41: 1-45.

Loeblich, A.R. Jr \& Tappan, H. (1988). Foraminiferal Genera and 
Their Classification. 970 pp. Springer Verlag, New York.

Matthäus, W. (1984). Zur mittleren jahreszeitlichen Veränderung von Temperatur und Salzgehalt in der Mecklenburger Bucht. Beiträge für Meereskunde 50: 9-23.

Menzel, U. (2009). CCP: Significance Tests for Canonical Correlation Analysis (CCA). Available at: https://cran.rproject.org/web/packages/CCP.

Murray, J.W. (1991). Ecology and Palaeoecology of Benthic Foraminifera. 397 pp. John Wiley and Sons, Essex, New York.

Murray, J.W. (2002). Introduction to Benthic Foraminifera. In S. Haslett (Ed.) Quaternary Environmental Micropalaeontology (pp. 5-13). Arnold: London.

Murray, J.W. \& Alve, E. (2011). The distribution of agglutinated foraminifera in European seas: Baseline data for the interpretation of fossil assemblages. Palaeontologia Electronica 14 (2) 14A: 41p. palaeo-electronica. org/2011_2/248/index.html.

Ojaveer, H., Jaanus, A., MacKenzie, B.R., Martin, G., Olenin, S. et al. (2010). Status of Biodiversity in the Baltic Sea. PLoS ONE 5(9): e12467.

Polovodova, I., Nikulina, A., Schönfeld, J. \& Dullo, W.-Ch. (2009). Recent benthic foraminifera in the Flensburg Fjord: distribution and response to environmental change. Journal of Micropaleontology 28: 131-142.

Powilleit, M., Kleine, J. \& Leuchs, H. (2006). Impacts of experimental dredged material disposal on a shallow, sublittoral macrofauna community in Mecklenburg Bay (western Baltic Sea). Marine Pollution Bulletin 52: 386-396.

Reaves, C.M. (1986). Organic matter metabolizability and calcium carbonate dissolution in nearshore marine muds. Journal of Sedimentary Research 56: 486-494.

Reimer, P.J., Austin, W.E.N., Bard, E., Bayliss, A., Blackwell, P.G. et al. (2020). The IntCal20 Northern Hemisphere Radiocarbon Age Calibration Curve (0-55 cal kBP). Radiocarbon 62: 725757.

Rößler, D. (2006). Reconstruction of the Littorina Transgression in the Western Baltic Sea. Marine Science Reports 67, 105pp.

Rößler, D., Moros, M. \& Lemke, W. (2011). The Littorina transgression in the southwestern Baltic Sea: new insights based on proxy methods and radiocarbon dating of sediment cores. Boreas 40: 231-241.

Ruiz-Agudo, E., Putnis, C.V. \& Putnis, A. (2010). Specific Effects of Background Ions on Magnesium Incorporation into Calcite. Revista de la Sociedad Espanola de Mineralogia 13: 187-188.

Seddon, A.W.R., Mackay, A.W., Baker, A.W., Birks, J.B., Breman, E. et al. (2014), Looking forward through the past: identification of 50 priority research questions in palaeoecology. Journal of Ecology 102: 256-267.

Siegel, H., Gerth, M., Heene, T., Ohde, T., Rüß, D. et al. (2009), Hydrography, currents and distribution of suspended matter during a dumping experiment in the western Baltic Sea at a site near Warnemünde. Journal of Marine Systems
75: 397-408.

Snoeijs-Leijonmalm, P. (2017). Patterns of biodiversity. In P. Snoeijs-Leijonmalm, H. Schubert \& T. Radziejewska (Eds.), Biological Oceanography of the Baltic Sea (pp. 123-19) Springer: Dordrecht.

Snoeijs-Leijonmalm, P. \& Andrén, E. (2017). Why is the Baltic Sea so special to live in? In P. Snoeijs-Leijonmalm, H. Schubert \& T. Radziejewska (Eds.), Biological Oceanography of the Baltic Sea. (pp. 23-84) Springer: Dordrecht.

Stuiver, M. \& Reimer, P.J. (1993). Extended 14C database and revised CALIB radiocarbon calibration program. Radiocarbon 35: 215-230.

Valchev, B. (2003). On the potential of small benthic foraminifera as paleoecological indicators: recent advances. Annual University of Mining and Geology "St. Ivan Rilski" 46: 189-194.

Weckström, K., Lewis, J.P., Andrén, E., Ellegaard, M., Rasmussen, P. et al. (2017). Palaeoenvironmental History of the Baltic Sea: One of the Largest Brackish-Water Ecocystems in the World. In K. Weckström, K.M. Saunders, P.A. Gell \& C.G. Skilbeck (Eds.), Applications of Paleoenvironmental Techniques in Estuarine Studies (pp 615-662). Springer: Dordrecht.

Witkowski, A., Broszinski, A., Bennike, O., Janczak-Kostecka, B., Bo Jensen, J. et al. (2005), Darss Sill as a biological border in the fossil record of the Baltic Sea: evidence from diatoms. Quaternary International 130: 97-109.

Zawisza, E. \& Szeroczyńska, K. (2007). The development history of Wigry Lake as shown by subfossil Cladocera. Geochronometria 27: 67-74.

Zettler, M.L., Bönsch, R. \& Gosselck, F. (2001). Distribution, abundance and some population characteristics of the ocean quahog, Arctica islandica (Linnaeus, 1767), in the Mecklenburg Bight (Baltic Sea). Journal of Shellfish Research 20: 161-169. 